\title{
Sustainable Land Arrangement Concept of Pondok Wage Indah 1 Housing in Industrial Area Sidoarjo
}

\author{
Rahardian Ari Wicahyo, Mimin Aminah Yusuf, Rika Kisnarini, Dewi Septanti \\ Departement of Architecture, \\ Sepuluh Nopember Institute of Technology Surabaya , \\ Keputih, Sukolilo, Surabaya City, \\ East Java, Indonesia 60111
}

\begin{abstract}
Industrial activities that have been developed cause the housing structure has changed according to the conditions that occur. The people get job opportunities with the presence of the industry, this is a positive impact felt by local people in improving socio-economic conditions.. However, the existence of the industry needed alertness to the negative impact caused because if not well controlled it will result in a decrease in the quality of the housing environment. This research was conducted to evaluate the arrangement of housing in industrial area. So it is expected that further development can minimize the negative impact of developing industrial estate. With sustainable development approach is expected to improve the quality of a better housing environment, so that people can improve their standard of living. The result of this research is the concept of housing arrangement in sustainable development based industry area in the form of maximizing green open space, maximizing road median, making policy of planting at least one tree and shrub every home, road improvement and arrangement of housing circulation.
\end{abstract}

Keywords: Arrangement Of Housing, Industrial Estate, Sustainable Development.

\section{INTRODUCTION}

The development of industry and infrastructure is a generator for the growth of settlements both in terms of quality and quantity. If the settlement land is not planned properly then there will be rapid and uncontrolled housing growth resulting in irregularities in the development of settlements (Widjajanti, 2004).

In the case of the development of Surabaya metropolitan city that leads to the suburbs of Gerbangkertasusila area (Gresik, bangkalan, mojokerto, Surabaya, Sidoarjo and Lamongan), Sidoarjo, Gresik and Mojokerto cities showed a very significant development in the field of industry (Meiriya, 2009).

The border area of Surabaya - Sidoarjo is an area whose industrial activities are growing quite rapidly. The area has undergone a transformation of a land function from agriculture or farm into housing and industry resulting in rapid urbanization along with its industrial development (Widjajanti, 2004).

One of the affected housing is Pondok Wage Indah 1 Sidoarjo. There are several problems that occur in this settlement area, one of which is the flood, public facilities are inadequate, green open space that has not been maximized and so forth.

\section{MATERIAL AND METHODOLOGY} Sustainable Development

The definition of sustainable development according to Silas (2001) is a development that can meet human needs for the moment without sacrificing future generations to be able to meet their needs. According to UNHABITAT (2012) sustainable development has three aspects that need to be considered, including the dimensions of ecology, economy and social culture.

In this research more focus on ecological aspect, based on UN-HABITAT (2012), sustainable development factor on ecology dimension, include: (a) Energy efficiency, water and other efficiency resources; (b) Eco-friendly design, using local materials and construction; (c) Sanitation and prevention of disasters and pollution from materials; (d) the use of affordable resources; (e) enhancing resilience and adaptation to occupancy. Meanwhile, according to Arifin (2009) ecological aspects that must be considered are as follows:

1. Located on suitable land and intended for resettlement

2. Spatial and efficient circulation network

3 . There is adequate clean water

4. There are drainage systems, sanitation and sewerage

5. Implementation of water absorption wells

6. Population density, size and quality of building meet

7. Minimum standards for the use of local materials and renewable energy

8. There are environmental housing facilities (health, education, worship facilities, market staples / shops, meeting hall, and security facilities)

9. Green open spaces (production, conservation, culture, recreation / social) at least $30 \%$

10. Affordability and ease of access to the workplace / market

11. Waste treatment so as not to endanger the local community and surrounding settlements

12. Maintaining local culture and wisdom (philosophy of protecting the environment, architectural design / building, the use of elements / ornaments, cultural / artistic activities and social system 


\section{Relation of Housing in Industrial Estate}

In the context of housing in industrial areas, according to Gunawan (1977) industrial activities will attract workers to settle nearby and the population growth will create the development of housing that the pattern and quality of the environment can not be separated from the existence of the industry. According to Widjajanti (2004), the positive impact of industrial estate on settlements besides the increasing of the people's economy is the improvement of infrastructure facilities in the settlement. While the negative impact is potentially a slum settlement, if the rapidly growing and uncontrolled growth of settlements that are anticipated too late and the pollution caused by the industry either in the form of air or water pollution.

According to the Permenperin 35 / M-IND / PER / 3/2010 Permenperin attachment in the Technical Guidelines of Industrial Zones, the matters that must be considered in industrial activities related to housing and settlement is the distance of industry to the minimum housing is $2 \mathrm{~km}$. Settlements in industrial areas have a positive impact in terms of fulfilling the needs of labor and product marketing aspects. In this case, it is also necessary to consider the additional need for housing as a result of the development of Industrial Estate. In relation to the distance to the settlement here must consider the problem of housing growth, where often the area of land around the industrial site becomes slum and there is no longer the distance between housing and industrial activities. While the industry has a negative impact because industrial activities produce pollutants and waste that can be harmful to public health.

The method used in this research is descriptive qualitative method and combined with design method. The first method used is descriptive qualitative which is done by observation and interview. Observation techniques used by using documentation, while interviews conducted to some local communities and also the housing manager. Interviews are used to determine the problems that occur in housing.

After the data obtained then the next use the design method that is by first analyze the variable amatan (physical condition of housing) associated with the concept of sustainable development. After that will be formulated the concept of sustainable housing arrangement in the industrial area.

\section{RESULTS}

Location Overview

The location is located in Pondok Wage Indah 1 Desa Wage Kecamatan Taman Kabupaten Sidoarjo. 6.7 hectare area and land designated as residential area (figure 1). Housing is adjacent to the industrial area, including PT. Ispat Indo, PT. Maspion and State Gas Company. Distance of housing from PT. Ispatindo is 900 meters, with PT Maspion 1200 meters and with Gedangan industrial area 4000 meters.

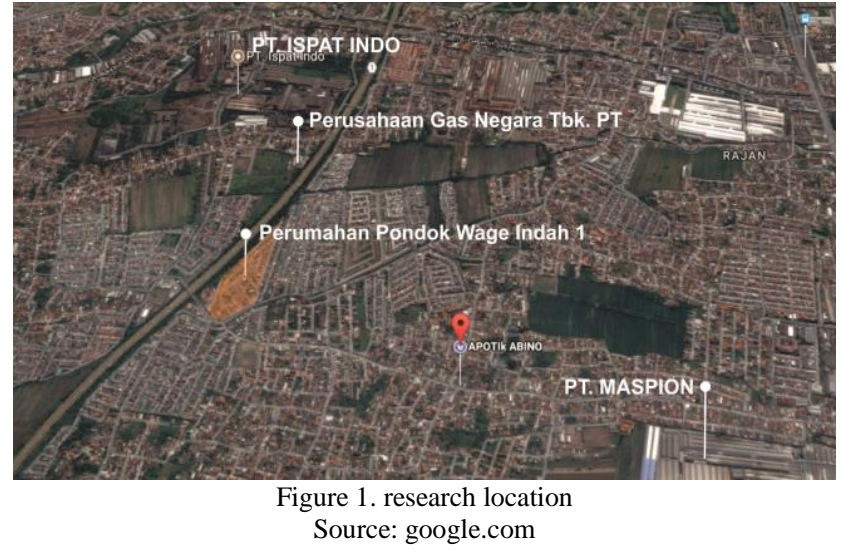

Discussion

Housing in the industrial area has the potential to be exposed to waste from industrial activity, whether solid waste, liquid or air. In this case, the industry closest to Pondok Pondok Wage Indah 1 Sidoarjo is PT. Ispat Indo, State-Owned Gas Company and PT. Maspion. Waste from PT. Ispat Indo and PT. Maspion of which is solid waste B3 from casting, printing, and coating that concentrate into category B3. B3 Solids enter the environment through water, soil, air, and animal media. Waste from a StateOwned Gas Company is carbon emissions (CO2).

The condition in the housing is not contaminated by solid and liquid waste, but the waste in the form of smoke that is distributed through the air causes damage to the housing environment, because it is also suspected that the housing condition is not sufficient $30 \%$ green open space (RTH) and RTH in poorly maintained housing and the condition of the house minimal greening.

In this case, to reduce $\mathrm{CO} 2$ emissions can be done by maximizing green open spaces that exist with trees and plants that can absorb high pollution. According to Iwan in Santoso (2011) the general character of a plant that has a high ability to absorb pollutants is a plant that has a lush canopy, not deciduous leaves, plants high. Characteristic plants that have high ability to reduce pollutant particles have the characteristics of the leaves, has a fine hair, rough surface leaves, scaly leaves, jagged leaf edge, needle leaf, sticky surface leaves, is effective to absorb pollutants. According to Trubus magazine (2009) the tuna that can reduce $\mathrm{CO} 2$ is trembesi, cassia, kenanga, pingku, banyan, krei umbrella, matoa, mahoni, saga, bungkur, teak, jackfruit, johar, soursop, puspa, acacia, flamboyant, and sawo kecik . In this housing some green open space that has not been maximized will be utilized as a park and playgraound. Here is an explanation:

\section{a. Playground}

Playground laid centered green open space in the north. This is because the vehicle access is not much so it is safe to use as a playground. The plant used is a type of plant that can produce more oxygen and use a tree titled to shade (figure 2). 


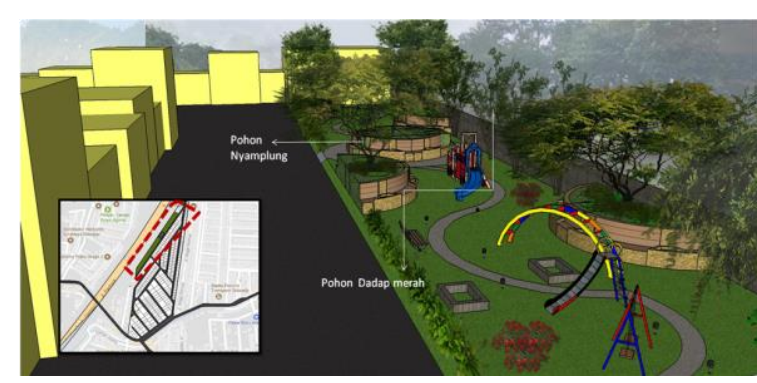

Figure 2. play ground design Source: author, 2017

\section{b. Garden}

Park in this housing is still not functioning optimally. In addition, the green open space capacity in the housing area is only 1.4 hectares or $22 \%$ of the 6.7 hectares of housing, so it has not met the minimum standard of green open space that is $30 \%$ (figure 3 ). Therefore the efforts made in maximizing the use of the park by optimizing the use of trees that produce oxygen a lot.

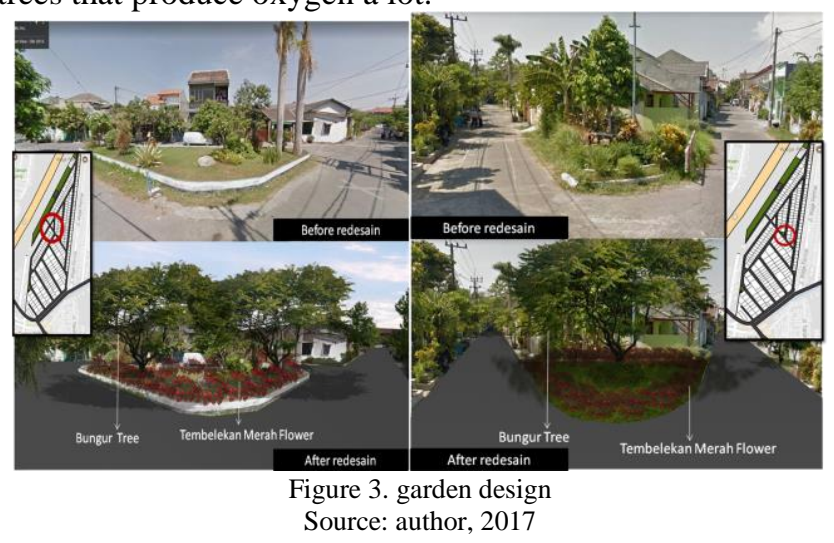

The median road in this housing often leads to misperception (figure 4). Because it is as if a linear path is one-way. So the proposal for the road median is to use a tree that is titled and a dense shrub tree. This is because the road is not impressed one way street linear.

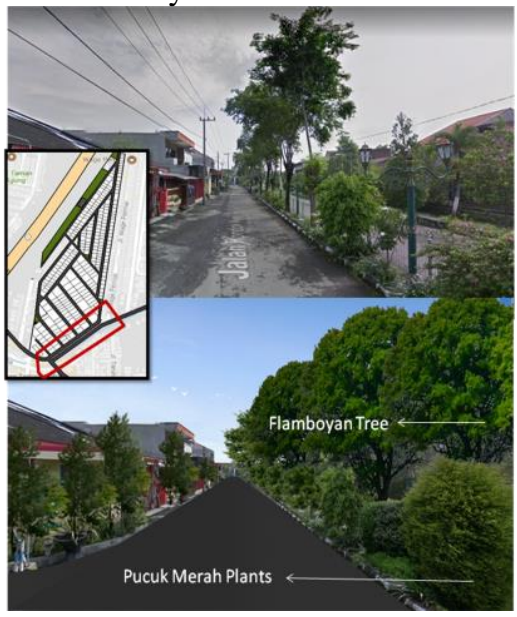

Figure 4. road median become garden Source: author, 2017

In addition to maximizing green open spaces in the form of parks, then to increase the green open space can be supported by applying a minimal policy of planting a tree or a plant per house citizens (figure 5). This effort is also done in addition in order to increase the amount of green open spaces also protect from pollution in the home scale

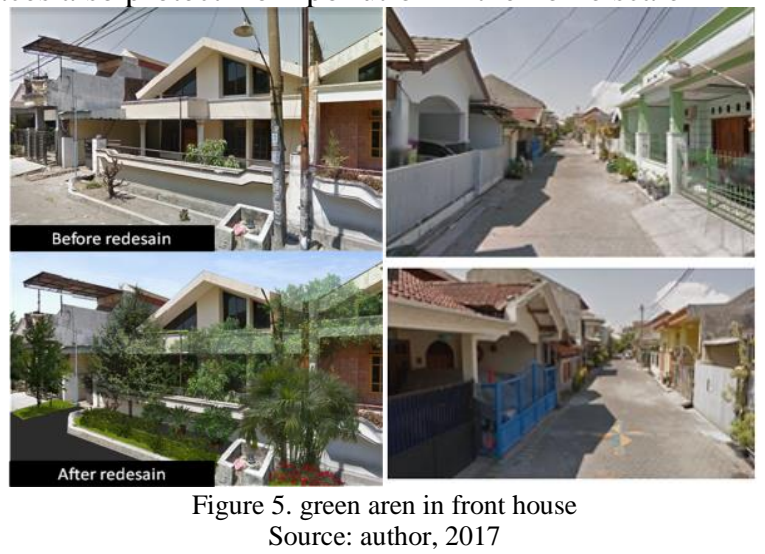

Another problem that exists in this housing is the presence of puddles in some streets housing when it rains (figure 6). It causes a damaged path. To fix the problem then the road that is still asphalt must be replaced with paving block (figure 7), then drainage can work normally because water level when rain on the gut is lower than the height of the road.

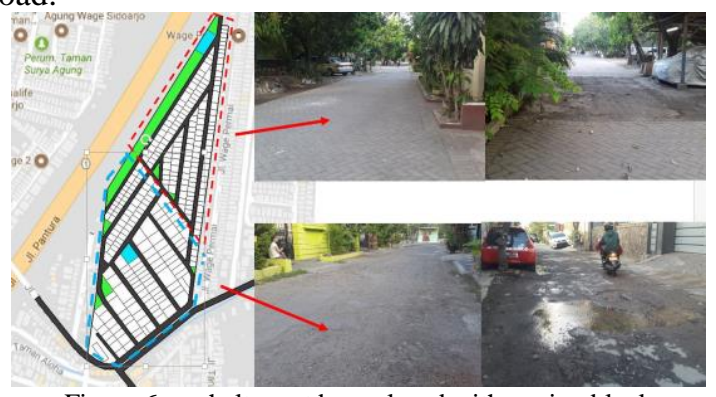

Figure 6. asphalt must be replaced with paving block Source: Author, 2017

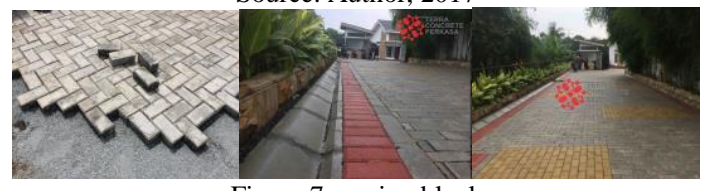

Figure 7. paving block

Source: terraconblock.com

The pondok wage indah adopts a one gate system for entry and exit. For security reasons this system is quite effective because the manager just enough to provide a security post to maintain. But in reality this housing system of one gate to make traffic passing vehicles to be crowded. This happens because the gate of a pondok wage indah adjacent to another housing, resulting in blind spots on passing motorists. Efforts that can be done to solve this problem is to create a separate entrance and exit lane, thus reducing the risk of crowded considering the front road of this housing is quite crowded by vehicle during rush hour (figure 8). 


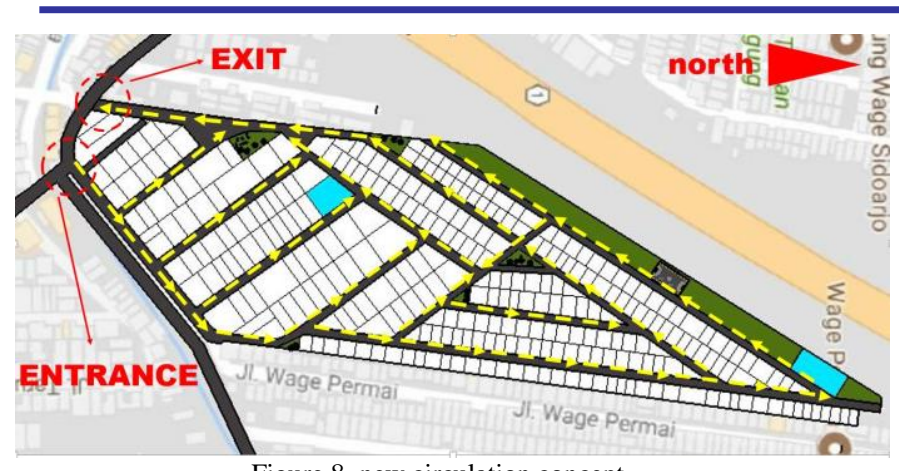

Figure 8. new circulation concept

Source: author, 2017

\section{IV.CONCLUSION}

Efforts made in the continuous arrangement of housing in beautiful wage huts are by means of maximizing green open spaces, maximizing road medians, making policy of planting at least one tree and shrub per house, road improvement and regulation of housing circulation.

\section{REFERENCES}

[1] Arifin, e. (2009). Permukiman Sehat Berwawasan Lingkungan Seri III.

[2] UN Habitat 2012

[3] Permenperin 35/M-IND/PER/3/2010 Industrial Area Technical Guidelines

[4] Widjajanti, Wiwik W. 2004. Pembangunan Berkelanjutan Pada Permukiman Di Kawasan Industri studi kasus : daerah perbatasan Surabaya - Mojokerto. Departement of Architecture, Institut Teknologi Adhi Tama Surabaya

[5] Silas, Johan, Kertas Kerja Pasca Sarjana ITS, 2001

[6] Gunawan, Mira P., Teori Lokasi, Perencanaan Fisik, 1977.

[7] Meiriya, Nungki. 2009. Pengendalian Perkembangan Kawasan MegaUrbanisasi Gerbangkertasusila Plus. ITS Surabaya

[8] Santoso, Suci N. 2011. Plant Application As Reducer Air Pollution. Departement of Environment Engineering. ITS Surabaya.

[9] Nasrullah, N., Heny, S., Soertini, G., Marietje W., dan Andi, G. 2000. Penggunaan Gas NO2 berlabel $15 \mathrm{~N}$ dalam Mengukur Absorbsi Polutan NO2 oleh Tanaman. Jakarta : Badan Tenaga Atom Nasional, Pusat Aplikasi Isotop dan Radiasi

[10] Trubus Magazine, 2009

[11] terraconblock.com 